\title{
Social Factors Influencing Household Solid Waste Minimisation
}

\author{
Nor Eeda Haji Ali ${ }^{1}$ and Ho Chin Siong ${ }^{2}$ \\ ${ }^{1}$ Department of Town and Regional Planning, Faculty of Architecture, Planning and Surveying, UiTM Seri Iskandar, Perak. \\ ${ }^{2}$ Department of Urban and Regional Planning, Faculty of Built Environment, Universiti Teknologi Malaysia.
}

\begin{abstract}
The growth of the world's population, coupled with increasing urbanization, and rising standards of living, have all contributed to the increase in solid waste generation. Solid waste disposal is becoming a difficult problem for many countries. Thus, efficient recycling of solid wastes is now a global concern for a sustainable solid waste management. Solid waste minimization is one of the ways of reducing the quantity of wastes for disposal. This study examines the perception of households towards solid waste minimization. 100 respondents were randomly selected from Section 7 housing area in Shah Alam city, Malaysia. Descriptive statistical technique was used in analysing the data. Findings from the study showed that respondent's knowledge on waste minimization was above average. However, their level of knowledge as revealed further by the results is not in tandem with their attitude on waste minimization, which suggests that their attitude towards waste minimization is low. People who showed higher knowledge do not necessarily show concern or perform in solid waste minimisation. Therefore, local authorities must develop appropriate policy strategies to change the attitude and behaviour towards waste minimisation if they are to reach their statutory targets.
\end{abstract}

\section{Introduction}

In the past two decades, solid waste management has become a major concern and is now one of the subjects discussed by the policy makers and planners. The highest solid waste generated in Malaysia is from residential sector, [15]. Annual growth rate of solid waste generation from household sector in Malaysian is continuously rising because of increasing urbanisation and rising standards of living. In Peninsular Malaysia (West Malaysia), the daily generation of waste escalated from 13,000 tonnes in 1996 to 19,100 tonnes in 2006 . Approximately $75 \%$ from this waste is disposed in landfills and dumps. An estimated $20 \%$ is burned or dumped into rivers or at illegal sites, while around $5 \%$ is recycled, [23]. Adopting an effective waste minimisation strategy by government is seen as another approach of sustainable municipal waste management.

Waste minimisation in Malaysia is not officially incorporated in to waste management practice. Malaysia launched the first official 3R's( Reduce, Recycle, Reuse) strategies in 1988 by Action Plan for a Beautiful and Clean Malaysia (ABC) where campaigns focused mainly on the recycling activities but the rate is still too low that it did not improve the existing waste management practice. The first recycling programme was introduced in Petaling Jaya in 1991 which involved source separation with kerbside collection. In 1996, Yellow Box Recycling Programme was launched, when 10,000 households were given recycling boxes where they can place their recyclables and collection was done weekly.
Recyclables were also collected by local authority, however the quantum collected was less than $1 \%$ of the total volume of municipal was generated. In the $21 \mathrm{st}$ century, the scenario of modern solid waste management such as waste minimisation, service delivery system, public awareness are challenging for both environmental and urban planners, [22].

Waste minimisation is a reduction of waste at source and the objective is to achieve a target of national solid waste hierarchy towards 2020. Solid waste hierarchy of Malaysia is to decrease the nation's solid waste generation by reduce, reuse, recycle, treatment and dispose. The Malaysia target for recycling is $22 \%$ of the total solid waste generated by the year 2020 . The current rate is far below the target and is approximately 5\%. Many stakeholders are involved in Malaysian waste minimisation. They include the Ministry of Housing and Local Government (formally known MHLG), National Solid Waste Management Department, Solid Waste and Public Cleansing Management Corporation, local authorities, concessionary companies, collectors and manufacturers, non-governmental organisations, private residents associations, educational institutions, private waste recycles, and others. The most common economic benefits derived from solid waste minimisation are cost avoidance, recycling revenue, reduced raw material costs, reduced energy costs, increased sales and increased productivity, [17].

Based on a recent survey by the Ministry of Housing and Local Government 2009, there are 100\% knowledge and awareness among the public about waste

noree038@perak.uitm.edu.my 
minimisation but very few are actually practicing it. Many factors contribute towards the failure of solid waste minimisation in Malaysia, such as lack of an efficient institutional framework and policies to promote it. Solid waste minimisation also involves efforts to minimise resources and energy to reduce environmental pollution. Integrating solid waste minimisation through recycling could help in reducing the challenges being faced in municipal solid waste management (MSWM). The objectives of the study are (i) to examine solid waste minimisation, waste composition and concept of solid waste minimisation (ii) to examine the social factors influencing solid waste minimisation (iii) to examine those factors hindering effective waste minimisation in the neighbourhood.

\section{Solid waste minimisation in urban housing}

\subsection{Municipal solid waste}

The most fundamental things to comprehend in solid waste management are solid waste generation, source and composition of the stream. Solid waste generated from various source such as residential, commercial, industrial etc. This generation must be controlled by stakeholders in order to achieve the government's target of solid waste minimisation in Malaysia [22\% by year 2020]. The sources of municipal solid waste are as follows:-

Table 1: Sources of solid waste generation

\begin{tabular}{|c|l|l|}
\hline No & $\begin{array}{c}\text { Sources of } \\
\text { Waste }\end{array}$ & \multicolumn{1}{|c|}{$\begin{array}{c}\text { Locations where wastes are } \\
\text { generated }\end{array}$} \\
\hline 1 & $\begin{array}{l}\text { Residential/H } \\
\text { ousing/ } \\
\text { Household }\end{array}$ & $\begin{array}{l}\text { Single and multifamily dwellings, } \\
\text { terrace, semi-detached, bungalow, } \\
\text { apartments and cluster house. }\end{array}$ \\
\hline 2 & Commercial & $\begin{array}{l}\text { Stores, hotels, restaurants, markets, } \\
\text { office buildings, motels, shops and } \\
\text { private school. }\end{array}$ \\
\hline 3 & Institutional & $\begin{array}{l}\text { Schools, hospitals, prisons, } \\
\text { government centers and } \\
\text { universities. }\end{array}$ \\
\hline 5 & Municipal & $\begin{array}{l}\text { Street cleaning, landscaping, parks, } \\
\text { beaches, water and open wastewater } \\
\text { treatment plants, recreational areas, } \\
\text { open spaces, treatment plant sites, } \\
\text { alleys, vacant lot, playgrounds and } \\
\text { roadside litter. }\end{array}$ \\
\hline 6 & $\begin{array}{l}\text { Agricultural } \\
\text { and } \\
\text { demolition }\end{array}$ & $\begin{array}{l}\text { Field and row crops, orchards, } \\
\text { vineyards, dairies, feedlots and } \\
\text { farms. }\end{array}$ \\
\hline 7 & $\begin{array}{l}\text { Industrial } \\
\text { New construction sites, road repair, } \\
\text { renovation sites, demolition of } \\
\text { buildings and broken pavement. }\end{array}$ \\
\hline Sources : & $\begin{array}{l}\text { Light and heavy manufacturing, } \\
\text { fabrication, construction site, } \\
\text { power, and chemical plants, } \\
\text { rrefineries, mineral extraction and } \\
\text { processing. }\end{array}$ \\
\hline
\end{tabular}

The growth rate of solid waste generation is continuously rising due to the world's population, increasing urbanisation, rising standards of living, and the rapid development of technology. Housing recorded the highest generated of solid waste which is $48 \%$, commercial $24 \%$, municipal services $11 \%$ and the slightly generated is from construction and demolition $4 \%$. The stakeholders involved have to play a serious role whether formal and informal.

Table 2: Sectors of solid waste generated

\begin{tabular}{|c|c|}
\hline Sectors & Percent \\
\hline Housing/Residential & 48.00 \\
\hline Commercial & 24.00 \\
\hline Municipal Services & 11.00 \\
\hline Agriculture & 7.00 \\
\hline Institutional & 6.00 \\
\hline Construction \& Demolition & 4.00 \\
\hline Total & 100.00 \\
\hline
\end{tabular}

\subsection{Concept of waste minimisation}

Waste minimisation or reduction is the process of reducing the amount in waste streams. The importance concept of waste minimisation in all countries is through 3R's (Reduce, reuse and recycling), [20] and treatment process (composting and incineration), [10]. Waste minimisation hierarchy is the concept of reducing solid waste in stream. It should be done progressively in order of importance, comfort and environment sustainability.

The process involves six steps ranked according to environmental impact. Reducing, which offers the best outcomes for the environment is at the top of the priority order, followed by preparing for reuse, recycling, composting, incineration and disposal. Treatment concept, which is in turn better than disposal to landfill. Looking at the pyramid of waste minimisation, reduction is the most preferred option while the landfill is seen as the least favoured option.

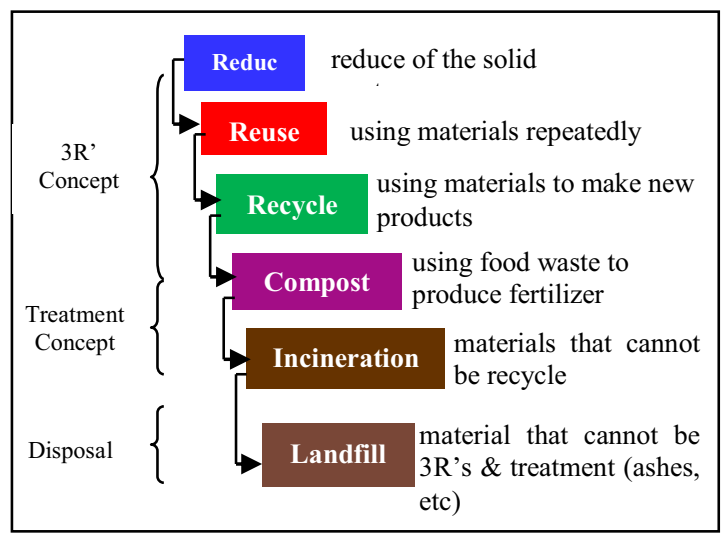

Figure 1: Waste minimisation hierarchy 


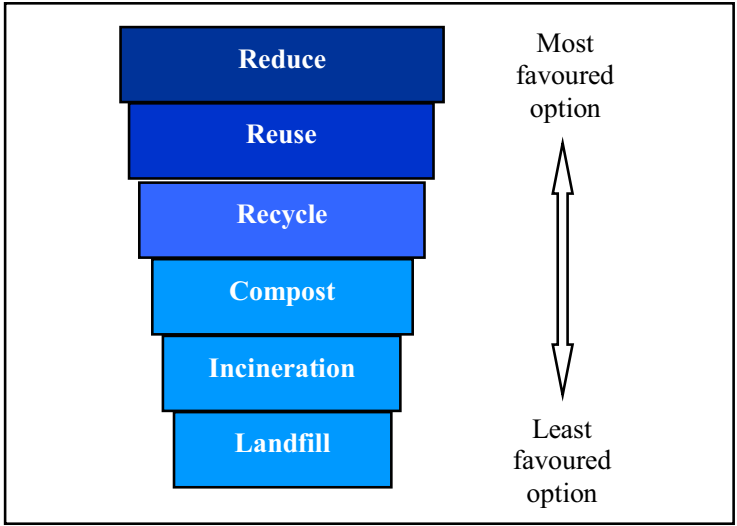

Figure 2: Pyramid of Waste Minimisation

\subsection{Social Factor Influencing Waste Minimisation}

There are many factors that influence solid waste minimisation. Among these factors are: social factor, physical factor, infrastructure factor, and institutions factor. This paper is only looking at the social factor with respect to knowledge and awareness of households on solid waste minimisation practices in residential areas of Shah Alam city.

\subsubsection{Knowledge}

Knowledge about recycling programs has a positive relationship with recycling practice. Generally, the more knowledge a household has about recycle materials and their impact on the natural world, the more likely they will practice it, [26]. S. Oskamp et al, (1991) noted that recycling behaviour may also be affected by lack of knowledge about environmental issues .People who showed higher knowledge and concerns about the environment and recycle, have higher levels of participation with recycling, [34], [27], [6], [31].

\subsubsection{Attitudes/Awareness}

The Theory of Planned Behaviour indicate not only predict behaviours from attitudes but also must observe the awareness through which the two are linked, [31]. General rule, the stronger the intention to engage in a behaviour, the more likely should be its performance in attitudes and awareness, [29]. If an individual is strongly motivated by something to behave a certain way, then they will likely do so. I.F. Ajzen, (1991) suggests that behaviour is not only guided by motivation, but also an individual's ability (attitude \& awareness) to engage in that behaviour. He calls this "behavioural control". The Theory Planned Behaviour also maintains that the greater the perceived control one has over a behaviour, the stronger the person's intention to perform that behaviour, [7]. I.F. Ajzen, (1991) confirms that performance of a behaviour is a joint function of intentions and perceived behavioural control. Perception variables (i.e. ease, difficulty) combined with intention variable (i.e. attitude) enables and individual's behavioural to be predicted.
K. Chan, (1998) found that personal attitude (based upon the individual's perception of the activity being right/wrong, good/bad, useful, desirable, pleasant and interesting) was by far the most important determinant of behaviour, with $\mathrm{PBC}$ and social norms much less so. K. Chan, (1998) speculated that social norms were not important in recycling behaviour because there is little or no social cost to individuals in not participating; but her study concerned 'bring' site recycling, whereas S. Barr (2007) research, which found that social norms were important, involved kerbside recycling, where the visual indication of not participating is much higher. Identifying motivators for and barriers to resident participation can help tailor recycling program parameters to meet the needs of residents.

\section{Methodology}

\subsection{Questionnaire Design}

The questionnaire was based on the waste minimisation literature and previous research. This questionnaire is comprised of close ended and open ended questions. The questionnaire contained of four following section:-

Section 1:

Demographic and background information regarding the respondents.

Section 2:

Knowledge. (Respondent was asked about the knowledge of waste minimisation).

Section 3:

Action on waste minimisation facilities/programs, which was launched.

Section 4:

Participation. Views or comments regarding the involvement/participation of Local Authorities.

Section 2 was measured using Likert Scales that typically ranged from 1 to 5 , whereby $1=$ Strongly disagree, $2=$ Disagree, $3=$ Neither agree or disagree, $4=$ Agree and $5=$ Strongly agree.

\subsection{The Data Collection}

The analysis of this study is based on primary data collected recently from three residential housing types (terrace, semi-detached and bungalow) in Section 4, Shah Alam, Selangor. The interview was conducted on persons who were above 18 years of age and were either the heads of households or families. The snowball sampling method was used for the data collection. Chi Square test will conducted for the analysis data. Enumerators were assigned to particular types of household in each area, with minimum interview quotas for each household type. A total of 100 questionnaires were administered and the proportions were $64 \%$ for terrace house and $18 \%$ for the semi-detached and bungalow respectively. The survey was conducted between 18th June -1st July 2014. The 
answers were coded and analyse using Special package for Social Science Statistics software (SPSS version 20).

\subsection{Case Study Selection}

The study was undertaken in Shah Alam, Selangor in Section 4. This area was chosen for the study because of two reasons. First, the section has recycling facilities some years now. Second, the various ethnic composition of the section gives impetus to a study of representative sampling of multi -ethnicity. The three ethnic groups Malay, Chinese and Indian are fully represented here.

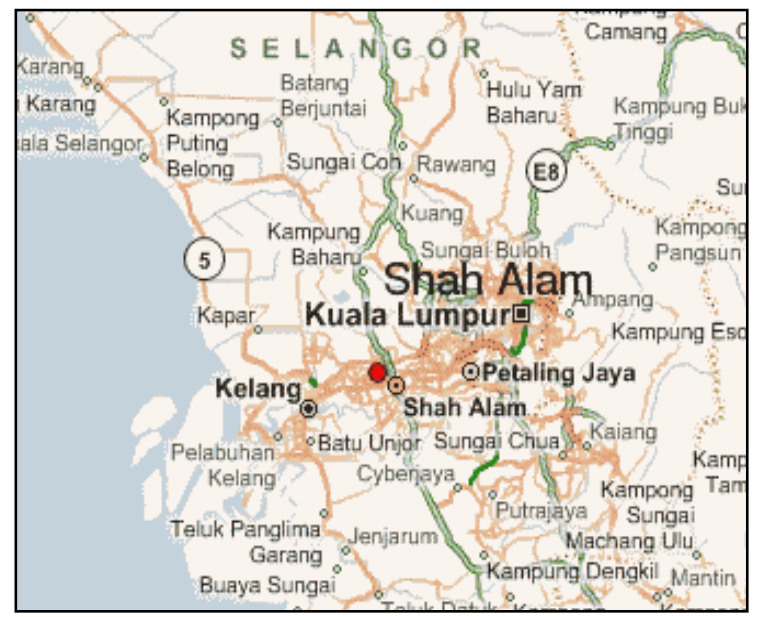

Figure 3: Key Plan

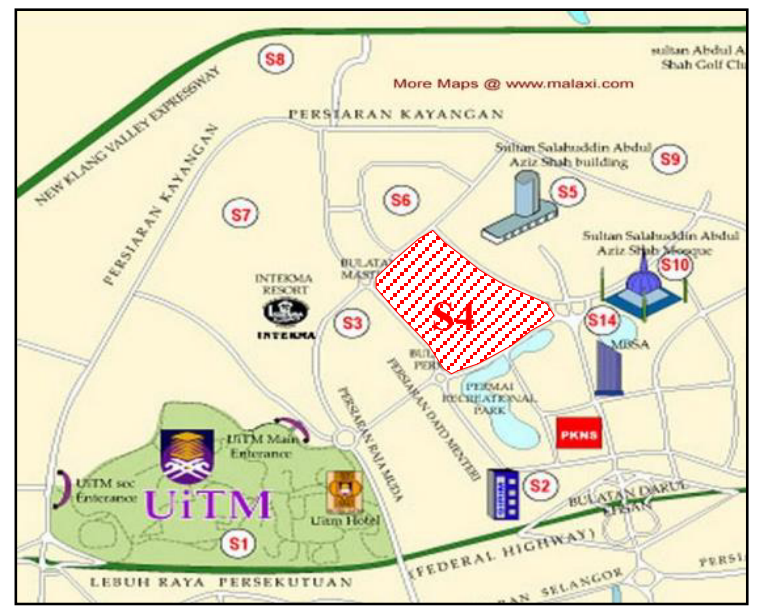

Figure 4: Plan Location

\section{Results}

\subsection{Demographic characteristics of respondents}

The gender profile indicates that $65 \%$ of those interviewed were males while only $35 \%$ were females. The data on age is presented in Figure 5, of the 100 respondents, those aged between 18 and 24 years represented $17 \%$. Those in the age range of 25 to 34 years constituted $29 \%$, while those aged between age 35 to 44 years and 45 to 54 years represented $13 \%$ and $21 \%$ respectively. Respondents above 55 years constituted only $20 \%$.

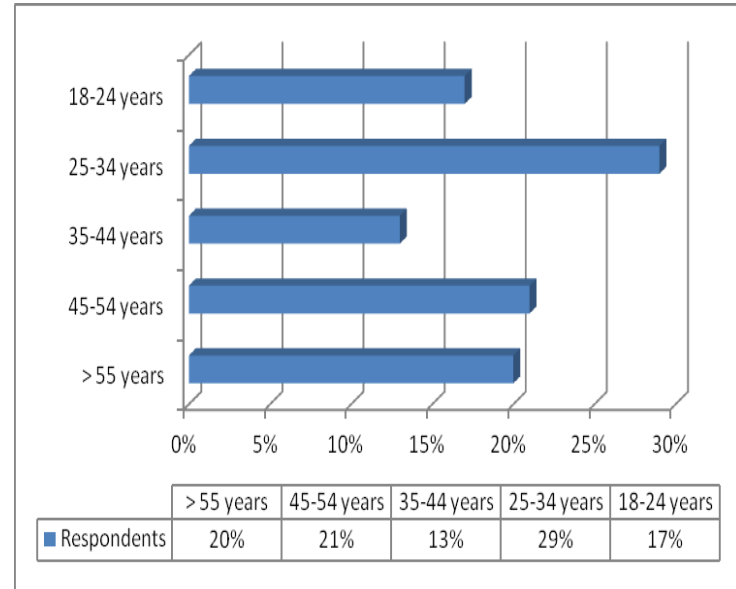

Source: Author's Fieldwork Survey, June 2014

Figure 5: Age distribution of respondents

Another important factor for socio-demography is occupation. About $35 \%$ of the respondents were professional, while $21 \%$ semi-professional while $14 \%$ and $9 \%$ were self-employed and unskilled respectively. The remaining $04 \%$ were housewife, $01 \%$ un-employed and $16 \%$ retiree (Figure 6 ).

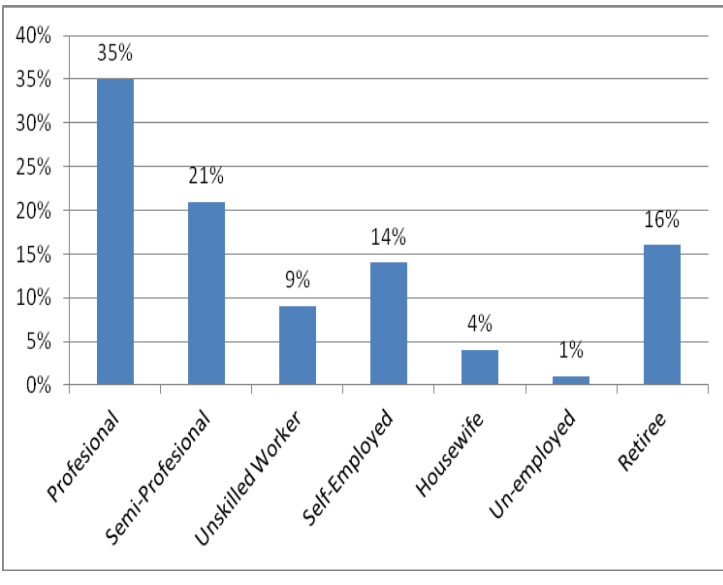

Source : Author's Fieldwork Survey, June 2014

Figure 6: Occupation attainments of respondents

The average monthly income of respondents was also considered an important variable that could influence household's knowledge and awareness on solid waste management system. The average monthly income obtained $41 \%$ of the respondents earned between RM2500-RM4999 monthly, 32\% earned more than RM5000 monthly, 21\% income around RM1000RM2499/month and 6\% respondents earners lowest RM1,000/month.

\subsection{Knowledge on waste minimisation}

In order to test for the level of knowledge of the respondents on waste minimisation, a Chi Square test was conducted. Results show that a significant difference exist in the level of knowledge of respondents on waste 
minimisation $(\mathrm{P}<0.05)$. Looking at the results in table 4 , majority $(92 \%)$ of respondents agreed that waste minimisation is good for clean environment while $8 \%$ remained neutral. The chi-square test, show that a significant difference exist $\left(\mathrm{X}^{2}=39.02(\mathrm{df}=2) \mathrm{P}<0.05\right)$. As could be seen $84 \%$ of the respondents agreed that waste minimisation helps in reduction of households solid waste generation while $13 \%$ were neutral and $3 \%$ disagreed. $\left(\mathrm{X}^{2}=49.52(\mathrm{df}=3) \mathrm{P}<0.05\right)$.

In contrast $63 \%$ of the respondents disagreed that households should not be involved in waste minimisation because it is for government and related public agencies while $12 \%$ remained neutral and $25 \%$ were agreed $\left(\mathrm{X}^{2}=\right.$ $25.30(\mathrm{df}=4) \mathrm{P}<0.05)$. On the knowledge about the quantity of waste being generated by household daily, $70 \%$ of the respondents agreed that were aware of the quantity of wastes generated in their household while $26 \%$ were neutral and $4 \%$ disagreed $\left(X^{2}=76.40(\mathrm{df}=4)\right.$ $\mathrm{P}<0.05)$.

Similarly, majority (91\%) respondents have knowledge about recycling and materials that can be recycled while 3\% respondent were neutral and 4\% respondent disagree. The chi-square test, show that a significant difference exist $\left(\mathrm{X}^{2}=72.72(\mathrm{df}=3) \mathrm{P}<0.05\right)$. Result showed that $90 \%$ of the respondents have seen the recycling bin before while 5 respondent were neutral and another 5\% claimed that they have never see it before $\left(\mathrm{X}^{2}=121.30(\mathrm{df}=4) \mathrm{P}<0.05\right)$.

In the similar vein, majority (72\%) agreed that they know the meaning of each of the colour bin while $25 \%$ were neutral and 33\% disagreed $\left(\mathrm{X}^{2}=62.00(\mathrm{df}=4) \mathrm{P}<\right.$ $0.05)$. A total of $66 \%$ agreed that they have been practicing recycling for a long time, $22 \%$ were neutral and $12 \%$ disagreed $(\mathrm{X} 2=56.10(\mathrm{df}=4) \mathrm{P}<0.05)$. Looking at the time collection of solid waste by daily, results show that $41 \%$ of the respondents agreed that they were aware of timing for recycling collection days in their housing area while $30 \%$ remained neutral and $29 \%$ disagreed $\left(\mathrm{X}^{2}=16.50(\mathrm{df}=4) \mathrm{P}<0.05\right)$.

A total of $43 \%$ respondent know where the collected waste will be sent to, while $34 \%$ respondent were neutral and $23 \%$ disagreed. The chi-square test, show that a significant difference exist $\left(X^{2}=20.500\right.$ $(\mathrm{df}=4) \mathrm{P}<0.05)$. Majority $(77 \%)$ respondent feel that there are weaknesses in the existing waste management system in Malaysia, while $34 \%$ were neutral and only $23 \%$ disagreed $\left(\mathrm{X}^{2}=74.70(\mathrm{df}=4) \mathrm{P}<0.05\right)$. Based on these results, it could be said that the level of knowledge residents of the neighbourhood has on waste minimisation is high.

Table 3: Knowledge on waste minimisation

\begin{tabular}{|c|l|c|c|c|c|c|c|c|c|}
\hline $\begin{array}{c}\text { Co } \\
\text { de }\end{array}$ & Knowledge & $\begin{array}{l}\text { S } \\
\text { D }\end{array}$ & D & N & A & $\begin{array}{c}\text { S } \\
\text { A }\end{array}$ & $\mathbf{X}^{2}$ & $\mathbf{P}$ & $\begin{array}{c}\text { d } \\
\text { f }\end{array}$ \\
\hline $\mathrm{W}$ & $\begin{array}{l}\text { Waste } \\
\text { minimisation is } \\
\text { good for clean } \\
\text { environment }\end{array}$ & - & - & 8 & 33 & 59 & 39.02 & .000 & 2 \\
\hline $\mathrm{W}$ & $\begin{array}{l}\text { Waste } \\
\text { minimisation in } \\
\text { helps } \\
\text { reduction of } \\
\text { households } \\
\text { solid waste } \\
\text { generation }\end{array}$ & - & 3 & 13 & 38 & 46 & 49.52 & .000 & 3 \\
\hline
\end{tabular}

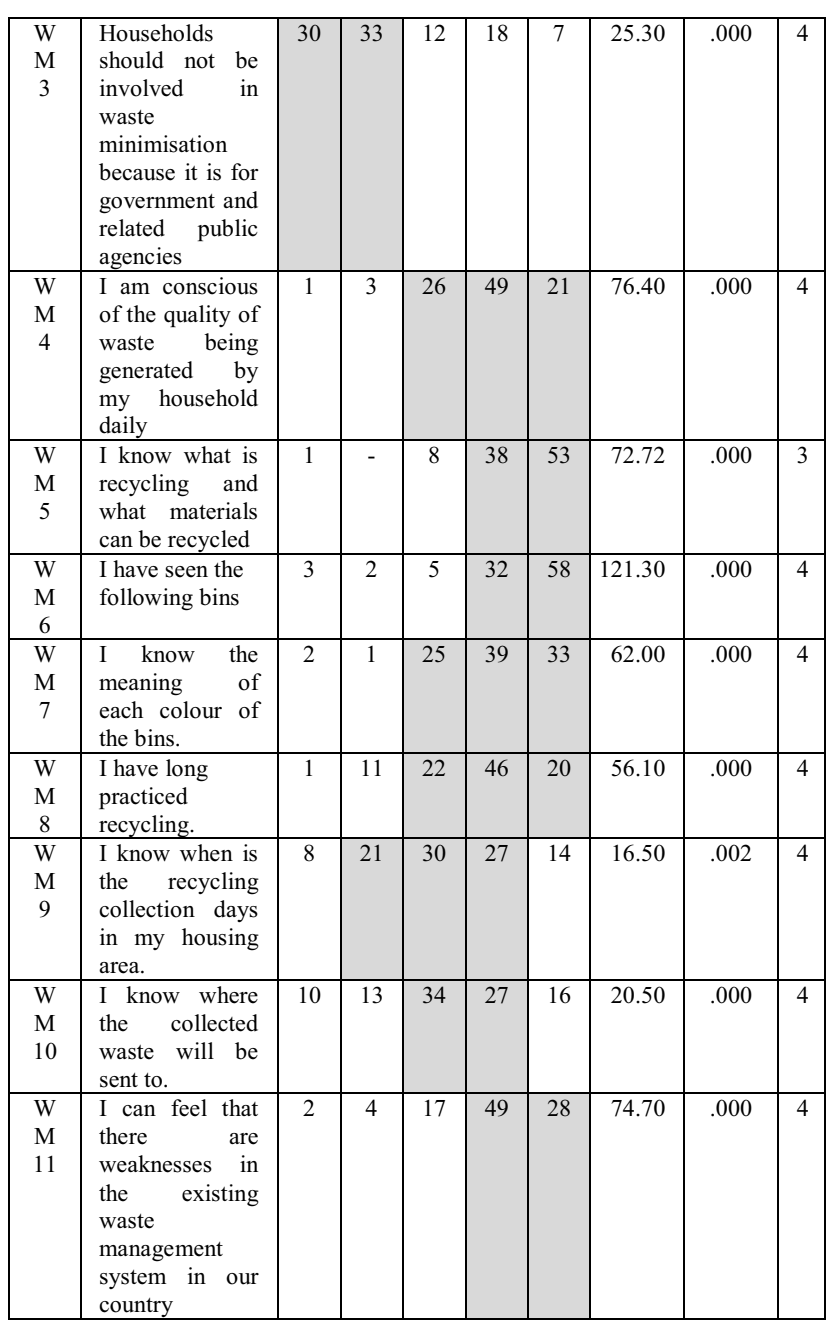

Source : Author's Fieldwork Survey, June 2014

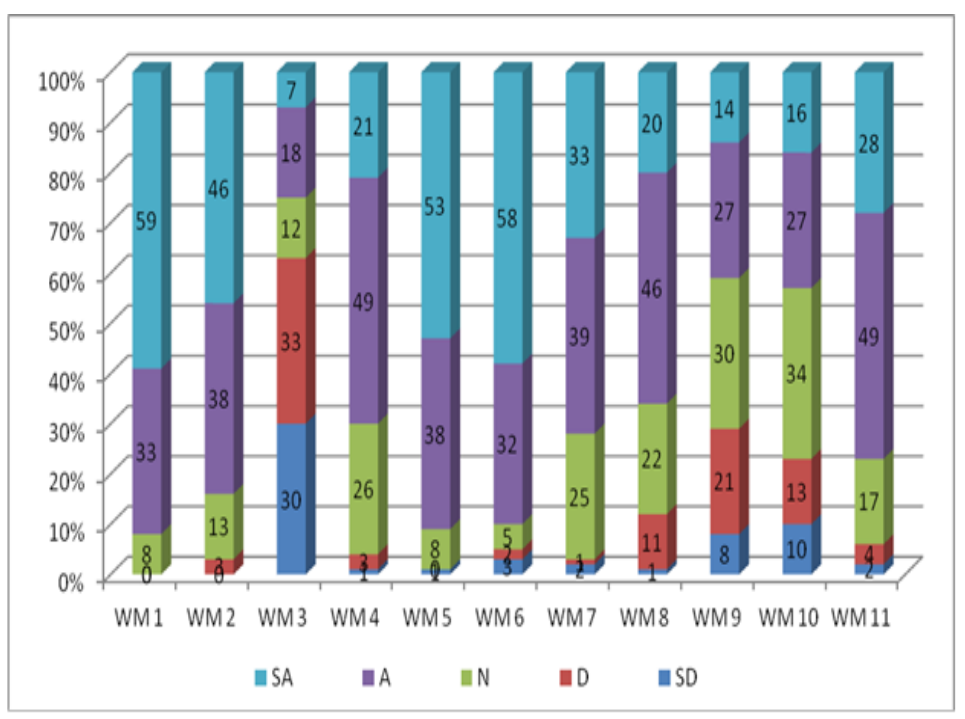

Source : Author's Fieldwork Survey, June 2014

Figure 7: Percent of knowledge on waste minimisation 


\subsection{Attitude/Awareness on waste minimisation}

Chi Square test was conducted in order to test for the level of attitude/awareness of the respondents on waste minimisation. Results show that a significant difference exist in the level of attitude/awareness of respondents on waste minimisation $(\mathrm{P}<0.05)$. As could be seen $61 \%$ of the respondents merely take initiative/effort in reduction of the quantity of solid waste they generate while $33 \%$ always make some effort in reducing their quantity of waste and 6\% never did so. Looking at the results in Table 10, 59\% of the respondents sometimes engage directly or indirectly in activities related to waste management or environmental conservation while $33 \%$ never and about $8 \%$ were fully involved $\left(\mathrm{X}^{2}=15.76 \mathrm{df}\right.$ $=3, \mathrm{P}<0.05$ ).

In contrast $44 \%$ of the respondents never used household waste recycling centres in other areas while $42 \%$ stated that they do some times and 14\% always use household waste recycling centres in other areas $\left(\mathrm{X}^{2}=\right.$ 19.12, df $=3, \mathrm{P}<0.05)$. Looking the respondents awareness on recycling, results show that $58 \%$ of respondents sometimes engage in recycling of such materials as tissues paper, bottle, and plastic , 30\% had always engaged in recycling while $12 \%$ never recycled any material before $\left(\mathrm{X}^{2}=32.24, \mathrm{df}=2, \mathrm{P}<0.05\right)$. Based on these results, it could be said that the level of awareness of residents in the neighbourhood has on waste minimisation is still low.

Table 4: Attitude/awareness on waste minimisation

\begin{tabular}{|c|c|c|c|c|c|c|c|}
\hline Code & Awareness & A & $\mathbf{S}$ & $\mathbf{N}$ & $\mathbf{X}^{2}$ & $\mathbf{P}$ & df \\
\hline $\begin{array}{c}\text { AWM } \\
1\end{array}$ & $\begin{array}{l}\text { How often do } \\
\text { you take the } \\
\text { initiative/effort to } \\
\text { reduce the } \\
\text { quantity of } \\
\text { garbage in your } \\
\text { household? }\end{array}$ & 33 & 61 & 6 & 38.64 & . 000 & 3 \\
\hline $\begin{array}{c}\text { AWM } \\
2\end{array}$ & $\begin{array}{l}\text { Have you been } \\
\text { involved directly } \\
\text { or indirectly with } \\
\text { activities related } \\
\text { to waste } \\
\text { management or } \\
\text { environmental } \\
\text { conservation? }\end{array}$ & 8 & 59 & 33 & 15.76 & .001 & 3 \\
\hline $\begin{array}{c}\text { AWM } \\
3\end{array}$ & $\begin{array}{l}\text { Do you use } \\
\text { household waste } \\
\text { recycling centres } \\
\text { in other areas? }\end{array}$ & 14 & 42 & 44 & 19.12 & .000 & 3 \\
\hline $\begin{array}{c}\text { AWM } \\
4\end{array}$ & $\begin{array}{lr}\text { Does } & \text { your } \\
\text { members } & \text { of } \\
\text { household use } \\
\text { recycled } \\
\text { materials } \\
\text { tissues as } \\
\text { bottle, plaper, } \\
\text { etc? }\end{array}$ & 30 & 58 & 12 & 32.24 & .000 & 2 \\
\hline
\end{tabular}

Source : Author's Fieldwork Survey, June 2014

On the point scale in SPSS, the ratings given as follows: never (0), depending on the circumstances (1), always (2).
For ease of interpretation, each rating is given the following denotation:-
Always
(A)
Sometimes
(S )
Never
(N)

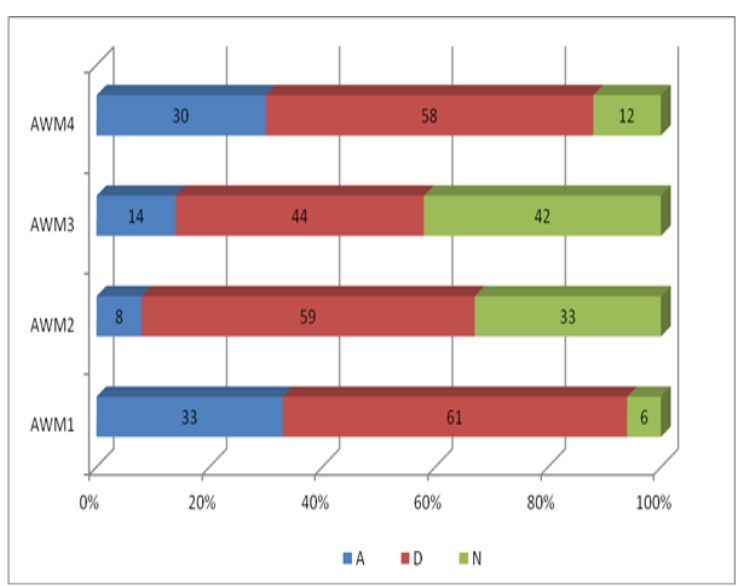

Source : Author's Fieldwork Survey, June 2014

Figure 8: Percent of attitude/awareness on waste minimisation

\subsection{Barriers to effective waste minimisation}

A total of $47 \%$ of the respondents stated that lack of public awareness from local authority give impact against waste minimisation. In addition, a total of $34 \%$ maintained that lack of recycling facilities is one of the barriers effective on waste minimisation. Other factors like political will of government $(5 \%)$, cost $(3 \%)$, vandalism of waste minimisation facilities $(6 \%)$ and nonlocation of collection points at strategic places $(5 \%)$ were identified as barriers in effective waste minimisation in the study area. When respondents were asked on what they feel should be done by government to improve waste minimisation in the area, they stressed the need for corporation by all stakeholders involved in the management of solid waste in the area. Also they want the creation of separation points for organic and inorganic wastes and more recycling plan.

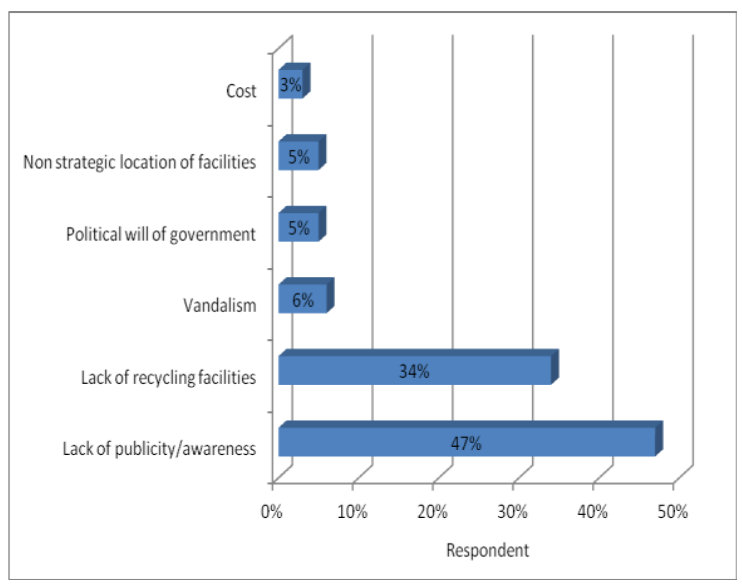

Source: Author's Fieldwork Survey, June 2014

Figure 9: Barriers to effective waste minimisation 


\subsection{Suggestions to improve waste minimisation}

On what needs to be done to improve waste minimisation in the study area, $30 \%$ of the respondents suggested more enlightenment campaign by the local authority on waste minimisation while $18 \%$ wants the creation of more recycle bins. A total of 13\% suggested the adoption a schedule for waste collection and $12 \%$ advocated the need for separation of the organic and inorganic wastes before their final disposal. Other suggestions made by the respondents include: cooperation of various stake holders involved in waste management, enforcement by government and taking a cue from other countries that have successfully implemented waste minimisation.

Table 5: Suggestions/recommendation for improve waste minimisation

\begin{tabular}{|l|c|}
\hline \multicolumn{1}{|c|}{ Suggestions/Commends } & $\%$ \\
\hline Creation of awareness on waste minimisation & 30.00 \\
\hline Create more recycling facilities & 18.00 \\
\hline Adopt a schedule for waste collection & 13.00 \\
\hline $\begin{array}{l}\text { Separation of collection points for organic and } \\
\text { inorganic wastes }\end{array}$ & 12.00 \\
\hline $\begin{array}{l}\text { Learn from other countries on how to practice waste } \\
\text { minimisation }\end{array}$ & 09.00 \\
\hline Enforcement by government & 07.00 \\
\hline $\begin{array}{l}\text { Fine defaulters who are found throwing recyclable } \\
\text { materials }\end{array}$ & 06.00 \\
\hline Corporation of all stakeholders & 05.00 \\
\hline \multicolumn{1}{|c|}{ Total } & $\mathbf{1 0 0 . 0 0}$ \\
\hline
\end{tabular}

Source : Author's Fieldwork Survey, June 2014

\section{Conclusions}

Solid waste minimisation is not a new concept in Malaysia. It has been applied in during 1980's. The level of knowledge the respondents have on solid waste minimisation as shown by the results of the study is high. However, this high level of knowledge has not translated to rapid decline in household solid waste generation due to the fact that the respondents are not aware of government's initiative on solid waste minimisation. The respondents seldom take initiatives that directly or indirectly reduce the quantity of wastes they generate. The Local Authorities must do something to increase the awareness among the households. This shows that a lot still needs to be done by Local Authority in the areas suggest such as creation of awareness on waste minimisation, create more recycling facilities, adopt a schedule for waste collection, learn from other countries on how to practice waste minimisation, enforcement by government, corporation of all stakeholders and fine defaulters who are found throwing recyclable materials. This could be done by injecting in new ideas in to the whole process of waste management from the collection, separation, recycling up to final disposal. This study has been able to assess urban solid waste minimisation in Shah Alam City Hall, Selangor could be improved with comparing other best practice.

\section{References}

1. A. William, A. Worrell and P.A. Vesilind, Second Edition : Solid Waste Engineering, (United States of America, 2012).

2. C. Chiemchaisri, W. Chiemchaisri, P. Somkliang and S. Threedeach, Seminar on solid waste landfill technology in Asia. (2006).

3. C. Chong, T. Lee, M. Matsufuji, L. Yasushi, Hassan, Mohd Nasir, Waste Management, 25, (2005).

4. D. Daniel, and L. Thomas, World Bank, Urban Development Sector Unit, East Asia and Pacific Region, (1999).

5. F. Kreith, G. Tchobanoglous, Handbook of Solid Waste Management, (McGraw Hill Professional, 2009).

6. G.C.C. Yang, Journal of Resources, Conservation and Recycling, 13, (1989).

7. I.F. Ajzen, Psychological Bulletin, 84, (1991).

8. J. J. Corbett, J. J. Winebrake, Journal of the Air and Waste Management Association, 58, (2005).

9. J. Pichtel, Waste Management Practices, (Taylor \& Francis, 2005).

10. J. Schall, Does The Solid Waste Management Hierarchy Make Sense? Working paper series, Programme on Solid Waste Policy, School of Forestry and Environmental Studies, Yale University, (1992).

11. K. Chan, Journal of Environmental Management, 52, (1998).

12. K. Sasikumar and S.G. Krishna, Solid Waste Management, (PHI Learning, New Delhi, 2009).

13. Malaysia Statistical Board, Basic Population Characteristics by Administrative District 2010. (Annual Report. Malaysia, 2010).

14. M.H. Nasir, Solid Waste Management in Malaysia: Can We Charter Future Strategies? In M.J. Jamaluddin, M. N. Mohd Jailani, S. Kamaruzzaman, S. Ismail and H.S. Abdul Hadi (Edt.). Proceedings of Realising Agenda 21: International Conference on Environmental Management: Ten years after Rio. Organised by Universiti Kebangsaan Malaysia (UKM), Bangi. 2002.

15. Ministry of Housing and Local Government, Malaysia, Waste Generation Statistics, (http://www.kpkt.gov., 2006).

16. Ministry of Housing and Local Government, Malaysia, Waste Generation Statistics, (http://www.kpkt.gov., 2009). 
17. Ministry of Housing and Local Government, Ministry of Housing and Local Government Reports 2010, (Kuala Lumpur, Government Printers, 2010).

18. Ministry of Housing and Local Government, National Solid Waste Management Report Volume 2, (National Solid Waste Management Department, 2011).

19. Ministry of Housing and Local Government, Solid Waste Management in Shah Alam, Selangor, Town \& Planning Department, (Majlis Bandaraya Shah Alam, 2013).

20. M.J. Franchetti, A Systems Approach Solid Waste. Analysis \& Minimization, (McGraw-Hill Companies, Inc. 2009).

21. M.O. Saeed, M.N., Hassan, M.A. Mujeebu, Waste Management, 29, (2009).

22. N. Yahaya, Solid Waste Management in Malaysia :Policy, Review, Issues and Strategies, Ministry of Housing and Local Government, Malaysia, (http://www.ea-

swmc.org/download/seminarlpapers/DrNazriYahay a.apf., 2007).

23. P. Agamuthu, S.H. Fauziah, Proceedings of the 2 nd Expect Meeting on Solid Waste management in Asia and the Pacific Islands, Kitakyushu, (2006).

24. P. Agamuthu, S.H. Fauziah, K.M. Khidzir, J Mater Cycles Waste Management, 11 (2009).

25. P. Agamuthu, K.M. Khidzir, S.H. Fauziah, Waste Management Res, 27, (2009).

26. P. Wesley Schultz, et. al, Knowledge, Information and Household Recycling:Examining the Knowledge-Deficit Model of Behavior Change, (New Tools for Environmental Protection, National Research Council, 1995).

27. R.J. Gamba, S. Oskamp, Environment and Behavior, 26, (1994).

28. S. Barr, Environment Behaviour. 39, (2007).

29. S. Oreg, T. Katz-Gerro, Environment Behaviour, 38, (2006).

30. S. Oskamp, M.J. Harrington, Edwards, T.C., Sherwood, D. L., Okuda, S. M. and D.C. Swanson, Environment and Behavior, 23, (1991).

31. S. Lee and H.S. Paik, Waste Management and Recycling Behaviour, 46 (2011).

32. Soncuya and Viloria, Solid Waste Management, 12, (1992).

33. T.V. Ramachandra, Management of Municipal Solid Waste, (Chaman Enterprises, New Delhi, 2006).
34. J. Vining, A. Ebreo, Environment and Behavior, 22 (1990). 